\title{
Views and Opinion of Rural Women of District Multan about their Involvement and Participation in Family Decisions: A Means for Women's Empowerment in Pakistani Society
}

\author{
Raazia Hassan Naqvi and Muhammad Ibrar
}

\begin{abstract}
It is the need of the time that females must also be provided with opportunities to participate in decision making, so that the pace of social development of the country could be accelerated. But unfortunately in our society women has not yet been given opportunities to make independent decisions in any important issue. She has to consult men and seek his consent and obey his command before taking any action. The study discussed that men are dominant in decisions over household and the other family members especially females. Men do not even consider the view point of the women before taking any family decisions. This may be because men are mostly earning members of the society or because they have more chances of academic qualifications so that they impose their decisions in all works on their women.
\end{abstract}

Index Terms-Education and awareness, family decisions, male dominance, women.

\section{INTRODUCTION}

Women's empowerment has five components: women's sense of self-worth; their right to have and to determine choices; their right to have access to opportunities and resources; their right to have the power to control their own lives, both within and outside the home; and their ability to influence the direction of social change to create a more just social and economic order, nationally and internationally [1]

Empowerment means getting or recovering one's power or giving power to someone else. Empowerment in true sense should result in a substantive shifting and relocation of resources. Empowerment can also be defined as a method of converting the relations of power among individuals and social groups, or changing social power by challenging the philosophy that rationalizes social inequality, for instance gender or caste; and by altering established prototypes of right to use and be in command of economic, natural and intellectual resources; and also by changing the institutions and structures that strengthen and uphold existing power arrangements such as the family, state, market, education, and media. While decision making is a course of action consisting of the activities which direct up to, or result in the selection of an option, of the commitment to a course of action. As societies struggle with integrating the theory of gender equality and gender sensitivity, female decision making is rapidly losing its label as a less important concern [2].

Manuscript received October 10, 2013; revised December 13, 2013.

Raazia Hassan Naqvi is with Department of Social Work, University of the Punjab, Lahore, Pakistan (e-mail: raazia03@hotmail.com).

\section{CONTEXT IN PAKISTAN}

Pakistan is an agricultural country. It has a vast rural sector with agrarian socio-economic set up. In Pakistan nearly $67.50 \%$ of the people are living in rural areas. Almost $70 \%$ of the population of the country is directly or indirectly dependent on agriculture. Agriculture provides the source of livelihood for the majority of rural families. In rural areas of Pakistan, women are actively involved in almost all of the agricultural activities along with their men in addition to their traditional domestic roles. Women's contribution in the agriculture sector is $66.4 \%$. Sowing, harvesting, ploughing, irrigation, storage of grain and seeds, raising and caring for livestock and poultry are some of the responsibilities of rural women in Pakistan [3].

Priorities and critical issues in social empowerment of women were identified as education and awareness, media, political will, attitudes, patriarchy, equality at home and at work, freedom of expression, social and physical mobility, ability to make decisions. Intra household inequality relates to differences in the economic bargaining power of different family members, and consequently the extent to which employment enhances women's domestic decision making power. Decision making in Pakistan, as in a great deal of South Asia, has been considered as a primarily male privilege. In relationship with their male equivalent, women are mostly ignored in economic, social, legal and political fields [4].

According to UNDP's Human Development Report 2012, Pakistan's position on Gender Inequality Index is 0.567 , the female to male ratio in Parliament is 0.270 , and the maternal mortality ratio (deaths of women per 100,000 live births) is 260. The adult female literacy rate (\%of females ages 15 and above) in Pakistan is $40 \%$ while that of males is $68 \%$ and over all literacy rates for adults of both sexes is 55\% [5]. A typical rural female in Pakistan is born into a poor, illiterate household, receives little education, marries at the age of 16 or 17, bears about seven children, and has a higher mortality risk than males during her reproductive period and a lower overall life expectancy than males [6].

\section{OBJECTIVES}

The objectives of the study were to find out the views and opinions of rural women about the different opposing grounds which restrict women in decision making process in the family and to suggest measures for the empowerment of rural women in Pakistan. 


\section{METHODS}

\section{A. Universe of the Study}

The universe of this research study was rural areas of District Multan. According to 1998 census of Pakistan, the total area of district Multan is 3656 square kilometer and the total population of district Multan including both sexes is $1,197,384$ which include 6,37,911 males and 5,59,473 females; the average household size is 7.47. According to the same source $24 \%$ of the total population of district Multan is living below the poverty line and women and girls remain highly vulnerable as this region is eminent for milestone cases in violence against women, sectarianism and expansion of extremist groups.
There are four tehsils (subdivision of a district) of district Multan, namely: Multan Cantonment, Multan Sadr, Shuja Abad and Jalalpur Pirwala. Total union councils (subdivision of a tehsil) are 126 including 51 urban union councils and 75 rural union councils. There are 537 mauzas/villages and one cantonment board in district Multan.

\section{B. Sampling Techniques and Tools of Data Collection}

Five rural union councils were selected by simple random sampling method. Then two each villages from each selected union council was drawn by lottery method. Thus the following rural union councils and their respective villages selected were as follows (See Table I).

TABLE I: NAME OF RURAL UNION COUNCILS AND RESPECTIVELY SELECTED VILLAGES.

\begin{tabular}{|l|l|l|l|}
\hline Union Council \# & Name of rural union council & Villages \\
\hline 60 & Nawabpur & Qadirpur Sandila & Mochiwala \\
\hline 59 & Binda Sandila & Jhokebalo & Guroowala \\
\hline 82 & $18 / \mathrm{MR}$ & $21 \mathrm{MR}$ & $18 \mathrm{MR}$ \\
\hline 86 & 5 Faiz & 05 Faiz & 4 Faiz \\
\hline 89 & Rana Wahin & Basti Chadhar & Peepalwala \\
\hline
\end{tabular}

Sample size of the research study consists of 120 female respondents from the above mentioned villages. The purposive sampling technique was used for the study and interviewing schedule was used to get primary data from the respondents. The interviewing schedule was semi-structured including both open ended and closed ended questions to get detailed information from the respondents.

\section{FINDINGS AND DATA ANALYSIS}

Table II shows the age groups of the respondents. The largest group of the respondents $(49$, or $40.7 \%)$ were of the age range of $16-25$ years; 35 or $29.2 \%$ of respondents were in the age group of 26-35 years; $31(26 \%)$ of respondents were from $36-45$ years, and five $(4.1 \%)$ respondents were up to 15 years.

Table III indicates the marital status and family system of the respondents. Majority of the respondents $97(80.9 \%)$ were married, $20(16.6 \%)$ respondents were unmarried and three $(2.5 \%)$ respondents were widows. The other part of the table shows that among the married respondents, the largest percentage (55 respondents, constituting 45.8\%) have joint family system, 33(27.6\%) respondents were living in nuclear families, and only nine $(7.5 \%)$ were living in extended families. Among the unmarried respondents, most of them 12 (10\% of the total sample, but $60 \%$ of the unmarried group) were living in joint families and only eight ( $40 \%$ of the unmarried women) were living in nuclear families. All the widow respondents were living in joint families.

TABLE II: AGE GROUPS OF THE RESPONDENTS

\begin{tabular}{|l|l|}
\hline \multicolumn{1}{|c|}{ TABLE II: AGE GROUPS OF THE RESPONDENTS } \\
\hline Age group (years) & Frequency \& Percentage \\
\hline Up to 15 & $05(4.1 \%)$ \\
\hline $16-25$ & $49(40.7 \%)$ \\
\hline $26-35$ & $35(29.2 \%)$ \\
\hline $36-45$ & $31(26 \%)$ \\
\hline Total & $120(100 \%)$ \\
\hline
\end{tabular}

TABLE III: MARITAL STATUS AND TYPE OF FAMILY OF RESPONDENTS.

\begin{tabular}{|l|l|l|l|l|}
\hline \multirow{2}{*}{ Marital status } & \multirow{2}{*}{ Trequency and \%age. } & Family system & \multirow{2}{*}{ Extended } \\
\cline { 3 - 5 } & & Nuclear & Joint & $09(7.5 \%)$ \\
\hline Married & $97(80.9 \%)$ & $33(27.6 \%)$ & $55(45.8 \%)$ & 0 \\
\hline Unmarried & $20(16.6 \%)$ & $08(06.6 \%)$ & $03(2.5 \%)$ & 0 \\
\hline Widow from & $03(02.5 \%)$ & 0 & 0 & 0 \\
\hline $\begin{array}{l}\text { Separated } \\
\text { husband }\end{array}$ & 0 & 0 & & 0 \\
\hline Total & $120(100 \%)$ & & & \\
\hline
\end{tabular}

The following Table IV is about the educational status of the respondents. Majority of the respondents $102(85 \%)$ were illiterate and $18(15 \%)$ were literate. The respondents who were illiterate were further asked about the opposing grounds of their educational rights and for majority of the respondents $56(46.6 \%)$ answered that their brothers were against their getting education and thus opposed their educational right, $30(25 \%)$ respondents replied that their parents opposed their getting education and 16 (13.4\%) respondents answered that their relatives opposed their educational right.

Among the respondents who were literate, 08 (6.6\%) 
respondents were educated till primary level, 05 (4.2\%) respondents were middle pass, $03(2.5 \%)$ respondents got education till matriculation and the educational level of 02
(1.7\%) respondents was intermediate. None of the respondents were educated up to graduation or post graduation.

TABLE IV: EDUCATIONAL STATUS OF RESPONDENTS AND IF ILLITERATE WHO OPPOSED EDUCATIONAL RIGHTS

\begin{tabular}{|l|l|l|l|l|l|l|l|l|l|}
\hline \multirow{2}{*}{$\begin{array}{l}\text { Educatio } \\
\text { nal status }\end{array}$} & \multirow{2}{*}{$\begin{array}{l}\text { Frequency } \\
\& \% \text { ages }\end{array}$} & \multicolumn{2}{|l|}{ Level of education } \\
\cline { 3 - 9 } & primary & Middle & $\begin{array}{l}\text { Matriculati } \\
\text { on }\end{array}$ & $\begin{array}{l}\text { intermedi } \\
\text { ate }\end{array}$ & $\begin{array}{l}\text { Graduation } \\
\text { above. }\end{array}$ & \& & Parents & Bright \\
\hline Literate & $18(15 \%)$ & $8(6.6 \%)$ & $5(4.2 \%)$ & $3(2.5 \%)$ & $2(1.7 \%)$ & 0 & - & - \\
\hline Illiterate & $102(85 \%)$ & - & - & - & - & - & $30(25 \%)$ & $56(46.6 \%)$ & $16(13.4 \%)$ \\
\hline Total & $120(100 \%)$ & & & & & & & \\
\hline
\end{tabular}

The following Table V shows the women's participation in decision making process. Among them majority of the respondents $70(58.4 \%)$ were not allowed to participate and say something in the family matters and 50 (41.6\%) respondents were allowed to participate in the family matters.

Among the respondents who were allowed to say something in family matters were further asked about the matters in which they could participate and are usually involved and it showed that $20(16.7 \%)$ respondents were allowed to say something in house hold matters, 14 (11.7\%) respondents were allowed to participate in children matters, while $2(1.6 \%)$ each could say something and participate in property and all matters of the family respectively.

TABLE V: WOMEN INVOLVEMENT AND PARTICIPATION IN FAMILY MATTERS.

\begin{tabular}{|c|c|c|c|c|c|c|}
\hline \multirow{2}{*}{$\begin{array}{l}\text { Are you allowed to say } \\
\text { something in family } \\
\text { matters }\end{array}$} & \multirow[b]{2}{*}{ Freq. } & \multicolumn{5}{|c|}{ If yes, in which matters } \\
\hline & & $\begin{array}{l}\text { Household } \\
\text { matters }\end{array}$ & $\begin{array}{l}\text { Decision } \\
\text { about } \\
\text { marriage }\end{array}$ & $\begin{array}{l}\text { Children } \\
\text { matters }\end{array}$ & $\begin{array}{l}\text { Property } \\
\text { matters }\end{array}$ & $\begin{array}{l}\text { In all family } \\
\text { matters }\end{array}$ \\
\hline Yes & $50(41.6 \%)$ & $20(16.7 \%)$ & $12(10 \%)$ & $14(11.7 \%)$ & $2(1.6 \%)$ & $2(1.6 \%)$ \\
\hline No & $70(58.4)$ & - & - & - & - & - \\
\hline Total & $120(100 \%)$ & & & & & \\
\hline
\end{tabular}

The above Table VI indicates the degree of consideration of respondents' decision in family matters and majority of the respondents $70(58.33 \%)$ said that their opinions in family matters are not at all considered while $27(22.5 \%)$ respondents' opinions were considered sometimes and 23 $(19.16 \%)$ respondents' opinions were considered mostly in family matters.

TABLE VI: CONSIDERATION OF RESPONDENTS’ OPINION IN FAMILY

\begin{tabular}{|c|c|c|}
\hline $\begin{array}{l}\text { How frequent your opinion in } \\
\text { family matters is considered }\end{array}$ & Frequency & $\%$ ages \\
\hline Mostly & 23 & $19.16 \%$ \\
\hline Sometimes & 27 & $22.5 \%$ \\
\hline Not at all & 70 & $58.33 \%$ \\
\hline Total & 120 & $100 \%$ \\
\hline
\end{tabular}

TABLE VII: OPINION OF RESPONDENTS REGARDING WHO SHOULD TAKE FAMILY DECISIONS.

\begin{tabular}{|l|l|l|}
\hline $\begin{array}{l}\text { Who should take decision } \\
\text { pertaining to family matters }\end{array}$ & Frequency & $\%$ ages. \\
\hline $\begin{array}{l}\text { Men as earning member } \\
\text { and as head of the family }\end{array}$ & 41 & $34.2 \%$ \\
\hline Woman & 23 & $19.2 \%$ \\
\hline Both man \& woman mutual & 56 & $46.6 \%$ \\
\hline Total & 120 & $100 \%$ \\
\hline
\end{tabular}

The following Table VII shows that majority of the respondents $56(46.6 \%)$ opined that both men and woman should mutually take decisions pertaining to family matters while $41(34.2 \%)$ said that men as they are the earning members and as such head of the family and only $23(19.2 \%)$ said that woman should take decisions pertaining to all family matters.

Table VIII indicates the hurdles in women's role in decision making process. Majority of the respondents 69 $(57.5 \%)$ said that old traditions and culture is the main hurdle in restricting women's role in decision making, while $38(31.66 \%)$ of the respondents were of the view that lack of education of women is the hurdle and only $13(10.83 \%)$ said that having no income is the hurdle in restricting women's role in decision making.

On further asking the respondents about how this situation can be improved, among the $69 \quad(57.5 \%$ respondents who said that old traditions and culture is the hurdle, $45(65.21 \%)$ said that education can improve the situation, while $17(24.63 \%)$ said that raising awareness among women about their rights can improve the situation and only $07(10.14 \%)$ said that preaching about golden Islamic values that promotes women's rights can improve the situation.

Among the $38(31.66 \%)$ respondents who said lack of education is the hurdle, $24(63.15 \%)$ said that imparting education to women can improve this situation while among the same respondents $9(23.68 \%)$ said that by preaching about golden and true Islamic values that gives rights to women can improve the situation and only $5(13.15 \%)$ said by raising awareness among women about their rights can improve the situation.

Among the respondents $13(10.83 \%)$ who said that 
having no income is the hurdle, majority $76(63.33 \%)$ said that education can improve the situation while $23(19.16 \%)$ said that raising awareness regarding women's rights can improve the situation and only $21(17.5 \%)$ said that preaching about golden Islamic values that promote women's rights can improve the situation.

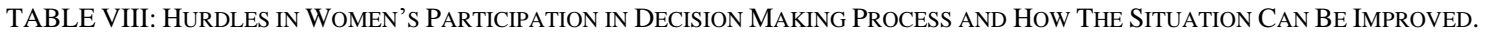

\begin{tabular}{|l|l|l|l|l|}
\hline \multirow{2}{*}{$\begin{array}{l}\text { Hurdles in women's role in decision } \\
\text { making }\end{array}$} & $\begin{array}{l}\text { Frequency } \\
\& \% \text { age. }\end{array}$ & \multicolumn{3}{|l|}{ How can we improve this situation } \\
\cline { 2 - 5 } & & Education & $\begin{array}{l}\text { Preaching about golden } \\
\text { Islamic values }\end{array}$ & $\begin{array}{l}\text { Raising } \\
\text { women's rights }\end{array}$ \\
\hline Lack of education & $38(31.66 \%)$ & $24(63.15 \%)$ & $9(23.68 \%)$ & $5(13.15 \%)$ \\
\hline Old traditions and culture & $69(57.5 \%)$ & $45(65.21 \%)$ & $07(10.14 \%)$ & $17(24.63 \%)$ \\
\hline Having no income & $13(10.83 \%)$ & $07(53.84 \%)$ & $05(38.46 \%)$ & $01(7.69 \%)$ \\
\hline Total & $120(100 \%)$ & $76(63.33 \%)$ & $21(17.5 \%)$ & $23(19.16 \%)$ \\
\hline
\end{tabular}

\section{SUMMARY OF MAJOR FINDINGS}

Majority of the respondents' age ranged from 16-25 years. Majority of the respondents were married. Majority of the respondents were illiterate. Majority of the respondents said that their brothers were against their getting education and thus opposed their educational right. Majority of the respondents were not allowed to participate and say something in the family matters. Majority of the respondents said that their opinions in family matters are not at all considered. Majority of the respondents opined that both men and woman should mutually take decisions pertaining to family matters. Majority of the respondents said that old traditions and culture is the main hurdle in restricting women's role in decision making, while some of the respondents were of the view that lack of education of women is the hurdle and only a few said that having no income is the hurdle in restricting women's role in decision making. Majority said that education can improve the situation.

\section{DISCUSSIONS}

The rural women of district Multan who were interviewed for the study belonged to young age. Most of them were married and living in joint family system where joint family system means more than one family living together in a house. Even the widows were living in joint families as in Pakistani society there is no concept of a woman living alone and running a household. Majority of the women were illiterate and those literate were educated up to only intermediate level (higher secondary) and none of the interviewed women was educated up to graduation and above. For most of the illiterate women their brothers, parents and even relatives opposed their education and did not allow them to attend any school as mostly in the country people consider girls/women education as futile as they think education for women is not necessary as they have to get married and raise children only so they need not to get education but should know only cooking and washing to be able to do household chores after marriage. The findings also suggest that even the relatives play negative role and influence the decisions regarding education of a girl in a family. This shows interference of close relatives like uncles and aunts etc. in family affairs.

The women living in rural areas of district Multan were not allowed to participate in decision making process of families as majority of them said that they were not allowed to say anything in decisions regarding family matters. And among those who participate in decisions they could only say about household management like what to cook today or child rearing matters like shopping for children clothing and telling when to feed a child. Further it was revealed that their involvement or saying was not considered while taking important family decisions like marriage, education, and inheritance matters. Some times their opinion is taken but not implemented considering them less intelligent or having less mental capacities.

In the opinion of majority of the rural women of district Multan, both man and woman of the house should take mutual decisions after consultation with each other for all the family matters while some also said that men as an earning member and as such head of the family should take all family decisions, they were ignorant of their rights about freedom of expression and freedom of making decisions along with their male counterparts.

Old traditions, customs and culture of the society in which woman is considered inferior and of less importance, was the main hurdle for majority of the rural women in their effective role in decision making problem while some were also of view that lack of education and lack of income for women are the causes of their restricted role in decision making process in the family affairs. For most of them education can improve their situation in making them independent and confident to take decisions regarding their families and themselves.

\section{CONCLUSION}

The women of Pakistan especially living in rural areas are subject to dominance by men of the family and we can say that there is patriarchal system of society in the country. Women are not allowed to say anything in the decisions regarding themselves and their families. Not even there are consulted before taking any decision about the family and even if they are involved their view point is not regarded or considered while taking final decisions. As the women themselves demanded right of education and wanted to get education so it is the responsibility of the state to provide them with educational facilities near their homes. But before that also the men of the family as oppose their education should be made aware of the advantages of the women education as the women have to build the home and the future generation of a family. The NGOs or other civil society organizations can also play an effective role in this regard by advocating and lobbying for women education in the society and those NGOs who are providing services in communities can set up nonformal schools for rural adult women in their areas. The challenge for these NGOs would be to run awareness raising programs for the men and women of the local communities and should raise awareness of freedom of expression and freedom of choice for women. 


\section{ACKNOWLEDGMENT}

The authors are thankful to the University of the Punjab, Lahore, Pakistan for providing financial resources for the study and Strengthening Participatory Organization (SPO) a national NGO of Pakistan for facilitation in the field and communities in District Multan. We are also highly indebted to the rural women who participated and gave consent to be interviewed for the study.

\section{REFERENCES}

[1] Secretariat of the United Nations Interagency Task Force on the Implementation of the ICPD Programme of Action. United Nations Population Information Network (POPIN) UN Population Division. Department of Economic and Social Affairs. Guidelines on Women's Empowerment. [Online] Available: http://www.un.org/popin/unfpa/taskforce/guide/iatfwemp.gdl.html

[2] S. Swartz. (February 2012). Decentralization, Local Development and Women's Empowerment: Innovating Knowledge and Practice. Universitas Forum. [Online]. 3(1). Available: http://www.universitasforum.org/ index.php/ojs/article/view/97/341

[3] Government of Pakistan, Population and Housing Census of Pakistan, 1998.

[4] Y. Zaidi, "Social empowerment of women," United Nations Development Program (UNDP) Workshop Report, Government of Pakistan, Pakistan, 1996.
[5] United Nations Development Program. (2013). The Rise of the South: Human Progress in a Diverse World. Human Development Report. [Online]. Available: http://www.hdr.undp.org

[6] H. M. Naqvi and U. K. Adeel, "Development, change and rural women in Pakistan," Pakistan Academy for Rural Development, Peshawar, 1994.

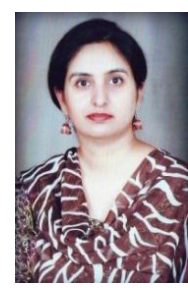

Raazia Hassan Naqvi is a Ph.D. scholar at Department of Social Work, Institute of Social Work, Sociology and Gender Studies, University of Peshawar, Khyber Pakhtunkhwa, Pakistan. She is also working as a lecturer with Department of Social Work, University of the Punjab, Lahore, Pakistan. She has work experience of almost twelve years with public and private sector of Pakistan. She has participated and presented research papers in many national and international conferences.

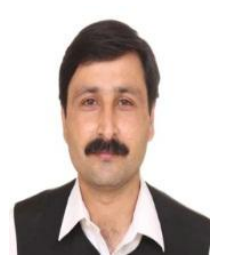

Muhammad Ibrar is a $\mathrm{Ph} . \mathrm{D}$. scholar, lecturer and coordinator at Department of Social Work, Institute of Social Work, Sociology and Gender Studies, University of Peshawar, Khyber Pakhtunkhwa, Pakistan. He has work experience of both public and private sector of Pakistan for more than five years. He has also participated and presented research papers in many national and international conferences. 